\title{
DINAMIKA USAHA, PENDAPATAN DAN POLA PENGELUARAN KONSUMSI PETAMBAK GARAM DI DESA PINGGIRPAPAS, KECAMATAN KALIANGET, KABUPATEN SUMENEP
}

\author{
Ahmad Azizi, Manadiyanto dan Sonny Koeshendrajana \\ Balai Besar Penelitian Sosial Ekonomi Kelautan dan Perikanan \\ JI. KS. Tubun Petamburan VI Jakarta 10260 \\ Telp. (021) 53650162, Fax. (021)53650159 \\ Diterima 31 Maret 2011-Disetujui 14 Oktober 2011
}

\begin{abstract}
ABSTRAK
Usaha garam berperan penting dalam pendapatan rumah tangga. Usaha garam tersebut mengalami fluktuasi dari tahun ke tahun, berakibat terhadap pendapatan dan pengeluaran rumah tangga. Penelitian ini bertujuan mengkaji karakteristik sosial ekonomi dan dinamika usaha tambak garam, tingkat pendapatan dan pengeluaran dari berbagai sumber mata pencaharian. Metode survey digunakan dalam penelitian ini. Sebanyak 32 sampel responden diambil secara acak dan dimonitor secara periodik. Data primer dan sekunder digunakan dalam penelitian ini. Data yang dikumpulkan meliputi karakteristik responden, tingkat pendapatan dan pola pengeluaran rumah tangga. Hasil penelitian menunjukkan bahwa $46,87 \%$ responden usaha petambak garam berpendidikan setingkat SLTP dengan kisaran pengalaman usaha 10 sampai 20 tahun. Tanggungan keluarga petambak garam berkisar antara 3- 6 orang. Kepemilikan lahan tambak garam $70,60 \%$ milik sendiri dan sisanya sebagai penggarap. Pendapatan zpetambak garam pada tahun 2007 adalah Rp. 31.900 .000 dan pendapatan pada tahun 2008 mengalami kenaikan menjadi Rp. 46.700.000, sedangkan tingkat pendapatan pada tahun 2009 petambak garam mengalami penurunan sekitar Rp.5.950.000 sehingga menjadi sebesar Rp. 40.750.000. Sumber pendapatan petambak garam yang hanya mengandalkan dari usaha garam, 53,13\% patambak garam yang sumber pendapatannya dari garam dan perikanan adalah $28,12 \%$, sedangkan petambak garam yang mata pencahariannya lebih dari dua adalah hanya $12,50 \%$. Pengeluaran untuk konsumsi rumah tangga pada tahun 2008 adalah sebesar Rp.15.444.000/tahun sedangkan pada tahun 2009 mengalami kenaikan menjadi Rp. 19.624.000.
\end{abstract}

Kata Kunci: dinamika, usaha, pendapatan, pengeluaran, tambak garam

\section{Abstract : Dynamics of Business, Income and Expenditure Patterns of Salt Farmers in Pinggirpapas Village, Kalianget of the Sumenep Regency. By : Achmad Azizi, Manadiyanto and Sonny Koeshendrajana.}

Salts production business plays an important role in the household income. This type of business is continued to fluctuate from year to year. This situation affect on household' revenue and expenditure. This research was aimed to analyse social and economic characteristics and dynamics of salt production business, level of income from various source of livelihood, and expenditure pattern of salt farmer household. A survey method was used in this study. Thirdty-two (32) respondent were randomly selected and monitored periodically. Primary and secondary data were collected. Data covered characteristic of respondents, business status, level of income and source and expenditure pattern of selected households. Results of the study illuetrated that educational level of salt farmer was mostly a junior high school (46.87\%), while business experiences range from 10 to 20 years. Family size was relative large (3-6 person/household). $70.60 \%$ of respondents are owner, while the remaining ones are tenants. In 2007, salt farmer's income was IDR 31.9 million, while in 2008 the income was increase to be IDR 46.7 million, then it was decreased by 5.95 million to become IDR 40.75 million. Salt farmer household who depended 
mainly on salt production business was 53.13\%, while who depended on both salt business and fisheries and more than two source of income were $28.12 \%$ and $12.50 \%$, respectively. In 2008, household expenditure of salt farmer was IDR 15.4 million, then it increased sharply to be IDR 19.6 million.

Keyword : dynamics, income, expenditure patterns, salt farmers

\section{PENDAHULUAN}

Garam sebagai komoditas produk kelautan mempunyai peranan penting dalam kehidupan sehari-hari maupun dalam sektor industri. Kebutuhan garam nasional dari tahun ke tahun semakin meningkat seiring dengan bertambahnya penduduk dan berkembangnya industri di Indonesia pada tahun 2000, kebutuhan garam nasional berkisar 855.000 - 950.000 ton/ thn untuk kebutuhan komsumsi dan 1.150.000 - 1.345.000 ton/thn untuk kebutuhan industri. Sehingga total kebutuhan garam sebanyak 2.100.000 - 2.200.000 ton/thn, sedangkan produksi garam 900.000 ton/ thn. Kebutuhan akan garam pada tahun 2008 mencapai 2.790 .000 ton, yang terdiri dari garam konsumsi 1.120.000 ton dan kebutuhan industri sebesar 1.670 .000 ton, produksi garam nasional sebesar 1.200 .000 ton sehingga untuk memenuhi kebutuhan tersebut harus mengimpor sebesar 1.630 .000 ton atau 157,89 persen (Jati dan Purwoko, 2009). Dengan kekurangan produksi garam nasional akan membuka peluang bagi petambak garam untuk meningkatkan produksi maupun membuka lahan baru untuk tambak garam, sedangkan menurut Manning dan Jayasura dalan Sugiarto (2008) lambatnya peningkatan produktivitas tenaga kerja adalah lambannya peningkatan upah riil buruh pertanian.

Saat ini luas tambak garam di Indonesia adalah 30.658 hektar terdiri dari luas pergaraman rakyat seluas 25.542 hektar dengan produktivitas maksimum 40 ton per hektar/musim dan luas pegaraman yang dikelola PT. Garam (Persero) 5.116 hektar dengan produktivitas maksimum
60 ton per hektar ( Sumahamijaya. 2009). Sampai tahun 2030 kebutuhan garam nasional diperkirakan mencapai 5.196.626 ton yang terdiri dari industri CAP (chlore alcali) 3.329.280 ton, garam rumah tangga 910.718 ton, industri aneka pangan/ pembersih 956.628 ton (Jati dan Purwoko, 2009). Apabila produktivitas garam nasional tidak ada peningkatan maka Indonesia akan terus menjadi negara pengimpor garam (Saad, 2006)

Pada saat ini, baik produktivitas dan kualitas garam rakyat relatif masih rendah, kondisi ini diperparah dengn harga garam yang tidak stabil, yang menyebabkan petambak garam makin terjepit. Kebijakan pemerintah tentang import garam mengakibatkan produksi garam lokal harus bersaing dengan garam import. Harga garam telah diatur dengan Peraturan Menteri Perdagangan No 08/2007 tentang Penetapan Harga Garam yang menetapkan disebutkan bahwa kualitas garam untuk K1 (Rp 750,- per kg), K2 (Rp. 550,- per kg). Dengan rendahnya produksi dan harga yang masih rendah akan berpengaruh terhadap pendapatan dan pola pengeluaran konsumsi rumah tangga petambak garam.

Secara umum kebutuhan akan konsumsi atau pengeluaran rumah tangga adalah berupa kebutuhan pangan dan kebutuhan non pangan, dimana kebutuhan keduanya berbeda. Pada kondisi pendapatan yang terbatas, masyarakat umumnya mendahulukan kepentingan kebutuhan konsumsi pangan, yang dapat dilihat pada kelompok masyarakat dengan pendapatan rendah. Pada kelompok masyarakat ini sebagian besar pendapatannya digunakan 
untuk memenuhi kebutuhan makanan dan modal untuk kebutuhan pengolahan lahan tambak garan berikutnya. Namun demikian seiring dengan pergeseran dan peningkatan pendapatan, porsi pola pengeluaran untuk pangan akan menurun dan meningkatnya pengeluaran untuk kebutuhan non pangan (Sugiarto, 2008).

Dari permasalahan tersebut diatas perlu dilakukan penelitian mengenai dinamika usaha, pendapatan, pengeluaran dan kondisi sosial untuk memberikan gambaran mengenai usaha tambak garam.

\section{METODOLOGI PENELITIAN}

\section{Waktu dan Lokasi Penelitian}

Penelitian dinamika usaha, pendapatan dan pola pengeluaran rumah tangga petambak garam dilaksanakan pada bulan Juli tahun 2009. Lokasi penelitian ditentukan berdasarkan potensi desa dari BPS tahun 2005. Desa yang terpilih adalah Desa Pinggirpapas, Kecamatan Kalianget, Kabupaten Sumenep. Lokasi tersebut merupakan sentra produksi garam dan dapat dianggap mewakili desa tambak garam karena desa tersebut memiliki lahan tambak garam terluas di wilayahnya.

\section{Metoda Pengumpulan Data}

Penelitian ini dilakukan dengan menggunakan metode survei. Data yang dikumpulkan adalah data primer dan data sekunder. Data primer dikumpulkan dari hasil wawancara dengan 32 responden menggunakan bantuan kuesioner. Pengambilan sampel dilakukan secara random sampling, data primer yang dikumpulkan adalah karakteristik responden dan pola pengeluaran rumah tangga petambak garam. Karakteristik reponden yang dikumpulkan adalah umur responden, pendidikan, pengalaman usaha dan jumlah tanggungan keluarga, sedangkan pengeluaran responden meliputi bahan makanan dan bukan bahan makanan. Responden yang menjadi sampel adalah petambak garam dengan status pemilik, penyewa dan bagi hasil, sedangkan data sekunder seperti jumlah petambak garam, potensi perikanan, areal luas pegaraman, produksi garam maupun jalur distribusi garam diperoleh dari instansi terkait seperti Kantor Desa Pinggirpapas, Dinas Kelautan dan Perikanan Kabupaten Sumenep dan PT. Garam (Persero). Analisis data dilakukan secara diskriptif dengan maksud untuk memberikan gambaran secara lengkap dan konperhensif tentang dinamika usaha dan pendapatan petani tambak garam.

\section{Analisis Data}

Data primer yang dikumpulkan ditabulasi silang dan dianalisis secara diskriptif untuk mengetahui gambaran mengenai karakteristik responden, dinamika pendapatan dan pengeluaran konsumsi rumah tangga. Data pengeluaran dibagi menjadi dua katagori pengeluaran yaitu pengeluaran bahan makanan dan bukan bahan makanan

\section{HASIL DAN PEMBAHASAN}

\section{Karakteristik Responden}

Karakteristik responden yang akan dikaji dalam penelitian ini adalah meliputi umur responden, tingkat pendidikan, pengalaman usaha, dan jumlah tanggungan keluarga. Dengan data karakteristik tersebut diharapkan dapat memberikan gambaran mengenai sebaran karakteristik pelaku usaha petambak garam.

\section{Umur Pelaku Usaha}

Umur merupakan faktor penentu dalam mencapai keberhasilan dalam suatu kegiatan usaha. Umur yang masih produktif akan lebih cepat dalam pengambilan keputusan suatu inovasi. Kisaran umur responden adalah antara 26-55 tahun. Sebaran umur responden petambak garam dapat dilihat pada Tabel 1 
Tabel 1. Sebaran Umur Responden Petambak Garam di Desa Pinggirpapas Kabupaten Sumenep, 2009.

Table 1. Age Distribution of Salt farmers in Pinggirpapas, Regency of Sumenep, 2009.

\begin{tabular}{cccc}
\hline No & $\begin{array}{c}\text { Kisaran Umur/ } \\
\text { Level Age }\end{array}$ & $\begin{array}{c}\text { Jumlah Responden/ } \\
\text { Number Respondent }\end{array}$ & $\begin{array}{c}\text { Persentase/ } \\
\text { Percentage }\end{array}$ \\
\hline 1 & $26-30$ & 2 & 6,25 \\
2 & $31-35$ & 6 & 18,75 \\
3 & $36-40$ & 7 & 21,88 \\
4 & $41-45$ & 9 & 28,13 \\
5 & $46-50$ & 5. & 15,62 \\
6 & $51-55$ & 3 & 9,37 \\
\hline & Jumlah/Total & $\mathbf{3 2}$ & $\mathbf{1 0 0}$ \\
\hline
\end{tabular}

Sumber : Data Primer diolah, 2009/ Source: Processing Primer Data, 2009.

Tabel 1 menunjukkan bahwa umur pelaku usaha termasuk kategori sangat produktif, dimana 18,75 persen responden berusia antara 31-35 tahun, kisaran umur pelaku usaha 36-40 tahun 21,88 persen, sedangkan kisaran umur $41-45$ tahun adalah 28,13 persen. Umur ini merupakan umur yang sangat potensial untuk melakukan kegiatan usaha dalam menerima inovasi baru. Hal ini sejalan dengan pendapat Manurung dkk (1984) mengatakan bahwa umur, pendidikan dan pengalaman akan berpengaruh terhadap pengambilan keputusan dalam mengadopsi teknologi yang akan digunakan.

\section{Tingkat Pendidikan}

Tingkat pendidikan petani tambak garam didominasi oleh petambak yang tingkat pendidikannya tamatan Sekolah Tingkat Pertama (46,87\%), hal ini dipengaruhi oleh tingkat pendapatan orang tuanya cukup rendah sehingga anaknya harus membantu pekerjaan orang tuanya. Disamping itu petambak garam tidak mempunyai keahlian lain seperti berkerja diluar sektor pegaraman yaitu buruh bangunan, pedagang atau jadi pegawai pabrik. Sebaran tingkat pendidikan responden dapat dilihat pada Tabel 2 di bawah.

Tabel. 2. Sebaran Tingkat Pendidikan Responden Tambak garam di Pinggirpapas Kabupaten Sumenep, 2009.

Table. 2. Distribution of Educational Level Salt Farmers in Pinggirpapas, Regency of Sumenep, 2009.

\begin{tabular}{llcc}
\hline No & \multicolumn{1}{c}{\begin{tabular}{c}
\multicolumn{1}{c}{ Tingkat Pendidikan/ } \\
Level Educattion
\end{tabular}} & $\begin{array}{c}\text { Jumlah Respoden/ } \\
\text { Total Respondent }\end{array}$ & $\begin{array}{c}\text { Persentase / } \\
\text { Percentage(\%) }\end{array}$ \\
\hline 1 & $\begin{array}{l}\text { Tidak Tamat SD/Droup out } \\
2\end{array}$ & $\begin{array}{l}\text { Tamat SD/ Primary school } \\
3\end{array}$ & $\begin{array}{l}\text { Tidak Tamat SMP/ Drouf out Junior } \\
\text { High School }\end{array}$ \\
4 & $\begin{array}{l}\text { Tamat SMP/ Graduated junior high } \\
\text { school }\end{array}$ & 5 & 15,63 \\
5 & Tamat SLTA/ High school graduation & 15 & 28,13 \\
\hline & Jumlah/Total & 3 & 96,87 \\
\hline
\end{tabular}

Sumber : Data Primer diolah, 2009./ Source: Processing Primer Data, 2009. 


\section{Pengalaman Usaha}

Pengalaman usaha merupakan salah satu modal utama yang sangat penting dalam melaksanakan kegiatan suatu usaha disamping pendidikan. Pengalaman dapat menentukan skala usaha yang akan dilakukan oleh responden. Semakin tinggi pengalaman usahanya semakin semakin cepat dalam mengambilan keputusan. Rata rata pengalaman responden tambak garam di lokasi riset adalah 15 tahun dengan kisaran pengalaman usaha adalah 5 sampai dengan 25 tahun. Sebaran pengalaman pelaku usaha tambak garam dapat dilihat pada Tabel 3. keluarga, Jumlah tanggungan keluarga yang sedikit tingkat kesejahteraannya akan lebih tinggi/baik bila dibandingkan dengan jumlah anggota keluarga yang lebih banyak. Jumlah tanggungan keluarga di lokasi riset cukup beragam mulai dari 2 orang sampai dengan 8 orang dan beberapa pendapatan responden pengatakan bahwa makin banyak jumlah tanggungan keluarga jumlah pendapatannya akan lebih banyak dan jarang responden yang mengikuti program keluarga berencanan. Sebaran jumlah tanggungan keluarga dapat dilihat pada Tabel 4 .

\section{Tabel. 3. Sebaran Tingkat Pengalaman Usaha Petambak Garam di Pinggirpapas, Kabupaten Sumenep, 2009.}

Table. 3. Business Experience Level Distribution of Salt farmers in Pinggirpapas Regency of Sumenep, 2009.

\begin{tabular}{lccc}
\hline No & $\begin{array}{c}\text { Pengalaman Usaha / } \\
\text { Business Experience }\end{array}$ & $\begin{array}{c}\text { Jumlah Respoden/ } \\
\text { Total Respondent }\end{array}$ & $\begin{array}{c}\text { Persentase / } \\
\text { Percentage(\%) }\end{array}$ \\
\hline 1 & $>5$ & & \\
2 & $5-10$ & 7 & 21,87 \\
3 & $16-20$ & 14 & 43,75 \\
4 & $21-25$ & 9 & 28,13 \\
5 & $>25$ & 2 & 6,25 \\
\hline & Jumlah & $\mathbf{3 2}$ & $\mathbf{1 0 0}$ \\
\hline
\end{tabular}

Sumber : Data Primer diolah, 2009./ Source: Processing Primer Data, 2009.

Tabel 3 menunjukkan bahwa petani tambak garam cukup berpengalaman, hal ini dikarenakan bahwa usaha tambak garam merupakan usaha yang sifatnya turun temurun dari orang tuanya. Kisaran pengalaman responden sebagai petani tambak garan 5-19 tahun adalah 21,87 persen dan pengalaman usaha yang kisarannya $16-20$ tahun adalah 4,75 persen, sedangkan responden yang pengalamannya 21 sampai 25 tahun adalah 28,13 persen dan 6,25 persen adalah responden yang mempunyai pengalaman lebih dari 25 tahun.

\section{Jumlah Tanggungan Keluarga}

Jumlah tanggungan keluarga sangat berpengaruh terhadap tingkat kesejahteraan
Tabel 4 menunjukkan bahwa jumlah tanggungan keluarga termasuk dalam katagori sedang yaitu berkisar antara 3 sampai 4 orang. Jumlah tanggungan keluarga yang paling besar adalah 3 sampai 4orang yaitu 65,62\%. Banyaknya jumlah tanggungan keluarga ini diakibatkan aktivitas responden yang kurang dan tidak mempunyai pekerjaan sampingan.

\section{Status Kepemilikan}

Luas lahan usaha tambak garam yang dikelola rakyat di Desa Pinggir Papas, beragam antara 0,5 - 5 hektar. Pola kepemilikan usaha tambak garam di Desa Pinggir Papas dapat dibagi menjadi dua kelompok yakni dikerjakan sendiri oleh pemilik dan 
Tabel. 4. Sebaran Jumlah Tanggungan Keluarga Petambak Garam di Pinggirpapas Kabupaten Sumenep, 2009.

Table. 4. Family Distribution Salt of Farmer in Pinggirpapas Regency of Sumenep, 2009.

\begin{tabular}{cccc}
\hline No & $\begin{array}{c}\text { Jumlah Tanggungan } \\
\text { Keluarga/ } \\
\text { Number of Family }\end{array}$ & $\begin{array}{c}\text { Jumlah Respoden/ } \\
\text { Total Respondent }\end{array}$ & $\begin{array}{c}\text { Persentase (\%) / } \\
\text { Precentage (\%) }\end{array}$ \\
\hline 1 & $<2$ & 1 & 3,13 \\
2 & $3-4$ & 21 & 65,62 \\
3 & $5-6$ & 8 & 25,00 \\
4 & $7-8$ & 2 & 6,25 \\
5 & $>8$ & & $\mathbf{1 0 0}$ \\
\hline
\end{tabular}

Sumber : Data Primer diolah, 2009/ Source: Processing Primer Data, 2009.

digarap orang lain melalui sistim bagi hasil. Berdasarkan status kepemilikan lahan tambak garam rakyat di Desa Pinggir Papas $70,60 \%$ milik pemilik, sedangkan oleh penggarap sebesar $29,40 \%$ Jumlah presentasi kepemilikan tambak garam yang terdapat di Desa Pinggir Papas sejak tahun 2002 sampai saat ini telah terjalin kerjasama antara petambak garam dengan PT. Garam (Persero) berupa penggarapan lahan tambak garam yang dikelola oleh petambak garam melalui kemitraan. Besarnya lahan tambak garam yang digarap petambak garam dalam pola kemitraan ini rata-rata hanya 0,5 hektar, sedangkan banyak pemilik tambak garam rakyat yang digarap oleh orang lain dengan cara sistem bagi hasil. Pola Kepemilikan lahan tambak garam di Desa Pinggirpapas tertera pada Tabel 5.

\section{Dinamika Usaha Petambak Garam}

Struktur Pendapatan Rumah Tangga Petani Garam

Secara umum pendapatan rumah tangga petani tambak garam diperoleh dari empat sumber pendapatan yaitu sumber pendapatan tambak garam, perikanan, toko sembako dan pedagang garam. Struktur sumber pendapatan masyarakat petani tambak tidak semuanya melakukan aktivitas usaha tersebut, ada beberapa petani yang mempunyai lebih dari dua sumber pendapatan. Struktur sumber pendapatan petani garam dapat dapat dilihat pada tabel 6 .

Pada umumnya petani garam di Desa Pnggir Papas menggantungkan pendapatan

Tabel 5. Status Kepemilikan Lahan Petambak Garam di Pinggirpapas, Kabupaten Sumenep, 2009.

Table 5. Load Ownership Status of Land Salt Farmers in Pinggirpapas Village of Sumenep, 2009.

\begin{tabular}{llc}
\hline No. & \multicolumn{1}{c}{$\begin{array}{c}\text { Status Kepemilikan Lahan/ } \\
\text { Load Ownership Status }\end{array}$} & $\begin{array}{c}\text { Persentase (\%)/ } \\
\text { Percentage (\%) }\end{array}$ \\
\hline 1 & Milik Sendiri/ Autochthonous & 70,60 \\
2 & Penggarap/ Cultivators & 29,40 \\
\hline & Jumlah/Total & 100 \\
\hline
\end{tabular}

Sumber : Data Primer diolah, 2009/ Source: Processing Primer Data, 2009. 
mereka sepenuhnya pada usaha garam. Responden yang mempunyai penghasilan dari dua sumber pendapatan adalah 28,12 \% yaitu dari usaha garam dan perikanan budidaya. Kegiatan perikanan budidaya dilakukan pada saat pada musim penghujan yaitu memanfaatkan lahan tambak garam sebagai kegiatan usaha budidaya ikan bandeng dan udang. Responden yang mempunyai tiga sumber mata pencaharian atau pendapatan adalah sebesar 12,50 persen, penghasilan tersebut terdiri dari usaha garam, perikanan dan pedagang garam (pedagang perantara) dan responden yang tambahan penghasilannya berasal dari toko sembako dan garam adalah 6,25 persen. Kegiatan usaha sembako setiap harinya kebanyakan dilakukan oleh istri responden dan dibantu oleh suaminya pada saat waktu luang.

Kegiatan usaha usaha tambak garam pada umumnya dilakukan pada musim kemarau mulai bulan yaitu Mei sampai Nopember atau pertengahan Desember, dengan musim puncak produksi garam terjadi pada bulan September - Oktober. Pada musim penghujan tambak garam oleh sebagian petani diusahakan untuk kegiatan usaha budidaya ikan bandeng dan udang secara tradisional. Sedangkan untuk musim hujan biasanya dimanfaatkan untuk menanam ikan bandeng ini terjadi di desa Pinggirpapas, Sumenep. Hal ini terjadi sejak turun temurun dan berlangsung sampai saat ini. Pemilik lahan tambak garam pada musim hujan tidak punya hak kepemilikan untuk memanfaatkan lahan tambak garamnya. Secara adat pada saat musim hujan turun hak penguasaan lahan beralih ke pemilik lain yaitu yang dimanfaatkan untuk usaha budidaya ikan.

\section{Dinamika Pendapatan}

Berdasarkan perhitungan analisis usaha petambak garam di desa Pinggirpapas Kabupaten Sumenep, tahun 2008 untuk pemilik yang digarap sendiri mengalami peningkatan sebesar Rp. Rp.11.350.000,- atau 57,47 \%, sedangkan tahun 2009 mengalami kenaikan Rp.1.900.000,- atau 6,1 \% begitu pula dengan usaha tambak garam yang dilakukan dengan sistem bagi hasil. Kenaikan keuntungan usaha ini disebabkan karena adanya kenaikan harga garam Rp.190.000,per ton (2008) menjadi Rp.230.000, per ton (2009).

Pola usaha petambak garam yang dilakukan baik yang berada di desa Pinggirpapas (Sumenep) mempunyai tiga sistem yaitu dikerjakan sendiri oleh pemiliknya, sistem bagi hasil dan sistim sewa. Pola pembagian usaha tambak garam yang dikerjakan dengan menggunakan sistem bagi hasil antara pemilik dan penggarap dibedakan

Tabel 6. Struktur Sumber Pendapatan Petani Tambak Garam di Desa Pinggirpapas, Kabupaten Sumenep, 2009.

Table 6. Source of Income Structure of Salt Farmers in Pinggirpapas Village of Sumenep, 2009.

\begin{tabular}{llc}
\hline No & \multicolumn{1}{c}{$\begin{array}{c}\text { Sumber Pendapatan/ } \\
\text { Source Pebdapatan }\end{array}$} & $\begin{array}{c}\text { Persentase (\%)/ } \\
\text { Percentage (\%) }\end{array}$ \\
\hline 1 & Petani garam / Farmers salt & 53,13 \\
2 & Petani garam + Perikanan/ Farmers Fisheries+salt & 28,12 \\
3 & Petani garam + Perikanan + Pedagang garam/ Farmers & 12,50 \\
& Salt + Fisheries + salt Marketing & 6,25 \\
4 & Patani Garam + Toko Sembako/ Farmers Salt + Stores & 100 \\
& Sembako & \\
\hline
\end{tabular}

Sumber : Data Primer diolah, 2009/ Source: Processing Primer Data, 2009 
dengan dua cara yaitu dibagi tiga setelah hasil bersih $1 / 3$ penggarap dan $2 / 3$ pemilik, apabila lahan tambak garam sudah lama diusahakan, sedangkan untuk lahan tambak garam yang baru diusahakan pembagian sistem bagi hasil yaitu 1 bagian untuk penggarap dan 1 bagian untuk pemilik.

Pelaksaan sistem bagi hasil seperti ini tidak menjamin atas kelangsungan dan keberlanjutan dari sistem bagi hasil, yang ada bahkan terjadi pemutusan hubungan sepihak. Di satu pihak, pemilik apabila merasa tidak puas terhadap hasil yang diperolehnya atau penggarap dianggap kurang memuaskan maka pemilik dapat menggantinya dengan penggarap yang baru. Sebaliknya, apabila penggarap merasa tidak ada kesesuaian maka penggarap dapat dengan mudah tidak melanjutkan usahanya sebagai penggarap. Hal ini bisa terjadi pada saat memasuki musim garam, dimana penggarap dengan mudah pindah ke pemilik yang lain. Dengan demikian sistim bagi hasil yang biasa dilakukan antara pemilik dan penggarap tidak memiliki kepastian hukum.
Sampai saat ini belum ada aturan tertulis yang mengatur tentang sistem bagi hasil garam baik berupa peraturan desa (Perdes) maupun peraturan daerah (Perda). Selama pelaksanaan sistem bagi hasil garam ini tidak diatur dalam peraturan resmi dan ada kemungkinan salah satu pihak yang dirugikan maka berpotnsi menjadi konflik. Untuk itu, di masa mendatang aturan sistem bagi hasil ini sebaiknya diatur dalam peraturan daerah sehingga kedua belah pihak baik pemilik maupun penggarap dalam melaksanakan bagi hasil memiliki aturan yang jelas dan kedua belah pihak memiliki payung hukum yang kuat yang ditetapkan pemerintah daerah sehingga keduanya memiliki jaminan dan kepastian hukum. Sebaran dinamika pendapatan rumah tangga petambak garam di Desa Pinggir Papas dapat dilihat pada Tabel 7.

Tabel 7, menunjukkan pendapatan rumah tangga petambak garam di Desa Pinggirpapas setiap tahun mengalami peningkatan. Dari tahun 2008 ke tahun 2009 dinamika pendapatan petambak garam mengalami peningkatan 6,2 persen.

Tabel 7. Dinamika Pendapatan Rumah Tangga Usaha Tambak Garam di Desa Pinggirpapas, Sumenep 2008- 2009.

Table 7. Dynamic of Salt Farmer's Household in Pinggirpapas Village of Sumenep 2008-2009.

\begin{tabular}{|c|c|c|c|c|}
\hline \multirow{2}{*}{$\begin{array}{c}\text { Sumber } \\
\text { Pendapatan/ } \\
\text { Revenue Sources }\end{array}$} & \multicolumn{4}{|c|}{$\begin{array}{l}\text { Pendapatan Rumah Tangga Petambak Garam/ } \\
\text { Household Income of Salt Farmers }\end{array}$} \\
\hline & 2008 & 2009 & $\begin{array}{l}\text { Perubahan/ Changes } \\
\text { (2009-2008) }\end{array}$ & $\begin{array}{l}\text { Keterangan/ } \\
\text { information }\end{array}$ \\
\hline $\begin{array}{l}\text { Tambak garam/ } \\
\text { Salt ponds }\end{array}$ & 31.100 .000 & 33.000 .000 & $(6,2)$ & Meningkat/Increased \\
\hline $\begin{array}{l}\text { Budidaya Ikan/ } \\
\text { Fish Farming }\end{array}$ & 1.850 .000 & 2.300 .000 & $(24,3$ & Meningkat/Increased \\
\hline $\begin{array}{l}\text { Toko Sembako / } \\
\text { Stores sembako }\end{array}$ & 13.750 .000 & 7.450 .000 & $(-45,8)$ & Penurunan/ Reduction \\
\hline $\begin{array}{l}\text { Pedagang garam/ } \\
\text { Salter }\end{array}$ & 3.250 .000 & 4.650 .000 & $(30,1)$ & Meningkat/Increased \\
\hline Jumlah /Total & 46.700 .000 & 40.750 .000 & $-12,8$ & \\
\hline
\end{tabular}

Sumber : Data Primer diolah, 2009/ Source: Processing Primer Data, 2009. 
Sedangkan perubahan tingkat pendapatan dari hasil budidaya ikan pada tahun 2008 adalah 12,1 dan pada tahun 2009 mengalami kenaikan yaitu 24,3persen, Dinamika pendapatan toko sembako pada tahun 2009 mengalami penurunan pendapatan sebesar $-45,8$ persen yang disebabkan pada tahun 2009 kemarau panjang sehingga petambak lebih baik dilakukan untuk kegiatan tambak garam.

Dinamika pendapatan usaha pedagang garam pada tahun 2009 mengalami peningkatan pendapatan yang cukup besar yaitu sebesar 30,1 persen. Tingginya pendapatan pedagang disebabkan pada tahun 2009 terjadi produksi yang besarbesaran yang diakibatkan oleh kamarau yang panjang, sehingga pedagang dapat memainkan harga di tingkat petani garam. Dinamika pendapatan usaha pedagang garam pada tahun 2009 mengalami peningkatan pendapatan yang cukup besar yaitu sebesar 30,1 persen, tingginya pendapatan pedagang disebabkan pada tahun 2009 terjadi produksi yang besar-besaran yang diakibatkan oleh kamarau yang panjang, sehingga pedagang dapat memainkan harga ditingkat petani garam.

\section{Pola Pengeluaran Rumah Tangga Petambak Garam}

\section{a. Pengeluaran Makanan}

Sugianto (2008), mengatakan bahwa secara umum besaran konsumsi pengeluaran rumah tangga dibagi menjadi tiga kelompok yaitu pengeluaran untuk makanan, bukan makanan dan pengeluaran bahan bakar. Umumnya besarnya tingkat pengeluaran petambak garam bervariasi tergantung besarnya tingkat pendapatan masingmasing rumah tangga petambak garam. Apabila pendapatannya rendah akan lebih mengutamakan kebutuhan pengeluaran pokok yaitu bahan makanan, sebaliknya apabila pendapatan yang dihasilkan tinggi akan terjadi pergeseran antara kebutuhan makanan dengan kebutuhan bukan makanan.
Pengeluaran rumah tangga petambak garan di Desa Pinggir Papas dibagi menjadi tiga katagori pengeluaran, yaitu pengeluaran makanan, bukan makanan dan pengeluaran bahan bakar ini sejalah dengan pemdapat Sugiarto (2008). Pola pengeluaran bahan makanan rumah tangga di Desa Pinggir Papas dilihat selama dua tahun dari tahun 2008 dan 2009 dan proporsi pengeluran bahan makanan rumah tangga petambak garam dapat dilihat pada tabel 8 .

Tabel 8 menunjukan dinamika pengeluaran bahan makan rumah tangga petambak garam di Desa Pinggir Papas, secara keseluruhan mengalami kenaikan Rp. 4.180.000,- atau 27, $06 \%$. Pengeluaran konsumsi terbesar di Desa Pinggir Papas, didominasi oleh pangan hewani pada tahun 2008 adalah 25,53\%, sedangkan pengeluaran konsumsi hewani pada tahun 2009 adalah 27,48\%. Pengeluaran konsumsi untuk hewani mengalami kenaikan sebesar $1,95 \%$, sedangkan pengeluaran untuk karbo hidrat pada tahun 2008 mencapai $20,05 \%$ dan pengeluaran yang terjadi pada tahun 2009 adalah 22,87\%.

Pengeluaran konsumsi untuk kacang kacangan (tahu dan tempe) biaya yang dikeluarkan untuk membelian kacang kacangan pada tahun 2008 sebesar $5,57 \%$ dan pada tahun 2009 sebesar 5,78\%. Pengeluaran untuk minyak goreng responden pada tahun 2008 adalah sebesar 2,19\% dan pada tahun 2009 sebesar 2,93\%. Kebutuhan tambahan energi responden adalah biaya untuk pembelian gula dan kopi, yang pada tahun 2008 adalah 3,75\% dan pada tahun 2009 sebesar $3,12 \%$.

Biaya pengeluaran pembelian kebutuhan dapur seperti bumbu pada tahun 2008 adalah sebesar 0,73\% dan pada tahun sebesar $0,76 \%$. Pengeluaran untuk makanan dan minuman yang sudah siap saji (aqua gelas, minuman botol, teh gelas dII) pada tahun 2008 adalah 17,18\% dan pada tahun 2009 sebesar 17,65 \% ini mengalami kenaikan sebesar $0,47 \%$, kenaikan pengeluaran untuk makanan dan minuman disebabkan banyak anak anaknya 
mengkonsumsi minuman dan makanan siap saji. Pengeluaran biaya untuk pembelian termbakau (rokok) pada tahun 2008 sebesar 17,99\% dan pad thun 2009 sebesar 12,22\%, hal ini untuk pengeluaran tembakau mengalami penurunan sebesar $5,77 \%$, penurunan ini sudah banyak petambak garam yang mengetahui bahaya dari asap rokok.

Biaya kebutuhan untuk buah buahan responden pada tahun 2008 adalah 2,48\% dari total biaya yang dikeluarkan, sedangkan pada tahun 2009 sebesar 2,15\%. Pengeluaran biaya kebutuhan ikan pada tahun 2008 adalah sebesar 8,70\%, dan pada tahun 2009 sebesar 9,78\%. Pengeluaran untuk kebutuhan ikan ini relatif kecil dibandingkan dengan pengeluaran kebutuhan lainnya, walaupun lokasi tersebut merupakan daerah nelayan dan termasuk lokasi pantai dan pesisir. $\mathrm{Hal}$ in disebebkan masyarakat petambak garam lebih suka pada karbo hidrat.

Tabel. 8. Proporsi Pengeluaran Bahan Makanan Rumah Tangga Petambak Garam di Kabupaten Sumenep, 2008-2009.

Table. 8. Proportion of Salt farmers Food Expenditure Household in Sumenep, 2008-2009.

\begin{tabular}{|c|c|c|c|c|}
\hline \multirow{2}{*}{ No } & \multirow{2}{*}{$\begin{array}{l}\text { Jenis makan/ } \\
\text { Food Category }\end{array}$} & \multicolumn{3}{|c|}{$\begin{array}{l}\text { Pengeluaran Bahan Makanan/ } \\
\text { Household Food Expenditure }\end{array}$} \\
\hline & & 2008 & 2009 & $\begin{array}{c}\text { Selisih (\%)/ } \\
\text { Difference (\%) }\end{array}$ \\
\hline 1 & $\begin{array}{l}\text { Sumber Karbohidrat / } \\
\text { Carbohydrate Source }\end{array}$ & $\begin{array}{r}3.096 .000 \\
(20,05)\end{array}$ & $\begin{array}{r}4.488 .000 \\
(22,87)\end{array}$ & 2,82 \\
\hline 2 & $\begin{array}{l}\text { Pangan Hewani/ } \\
\text { Food Animal }\end{array}$ & $\begin{array}{r}3.480 .000 \\
(25,53)\end{array}$ & $\begin{array}{r}4.608 .000 \\
(27,48)\end{array}$ & 1,95 \\
\hline 3 & Ikan/ Fish & $\begin{array}{r}1.344 .000 \\
(8,70)\end{array}$ & $\begin{array}{r}1.920 .000 \\
(9,78)\end{array}$ & 1,08 \\
\hline 3 & Kacang-Kacangan/ Nuts & $\begin{array}{r}860.000 \\
(5,57)\end{array}$ & $\begin{array}{r}1.056 .000 \\
(5,38)\end{array}$ & $-0,19$ \\
\hline 4 & $\begin{array}{l}\text { Sayur sayuran/ } \\
\text { Vegetables }\end{array}$ & $\begin{array}{r}480.000 \\
(3,11)\end{array}$ & $\begin{array}{r}576.000 \\
(2,93)\end{array}$ & $-0,18$ \\
\hline 5 & $\begin{array}{l}\text { Minyak dan Lemak/ } \\
\text { Oils and Fats }\end{array}$ & $\begin{array}{r}432.000 \\
(2,19)\end{array}$ & $\begin{array}{r}576.000 \\
(2,93)\end{array}$ & 0,73 \\
\hline 5 & $\begin{array}{l}\text { Buah buahan/ Fruit } \\
\text { trees }\end{array}$ & $\begin{array}{r}384.000 \\
(2,48)\end{array}$ & $\begin{array}{r}480.000 \\
(2,15)\end{array}$ & $-0,04$ \\
\hline 6 & $\begin{array}{l}\text { Bahan Minuman/ } \\
\text { Beverage Ingredients }\end{array}$ & $\begin{array}{r}564.000 \\
(3,75)\end{array}$ & $\begin{array}{r}672.000 \\
(3,12)\end{array}$ & $-0,63$ \\
\hline 7 & Bumbu-Bumbu/Spices & $\begin{array}{r}144.000 \\
(0,73)\end{array}$ & $\begin{array}{r}168.000 \\
(0,76)\end{array}$ & 0,03 \\
\hline 8 & $\begin{array}{l}\text { Makanan dan Minuman } \\
\text { Jadi/ Food and } \\
\text { Beverage So }\end{array}$ & $\begin{array}{r}2.500 .000 \\
(17,18)\end{array}$ & $\begin{array}{r}2.680 .000 \\
(17,65)\end{array}$ & 0,47 \\
\hline 9 & $\begin{array}{l}\text { Tembakau dan Sirih/ } \\
\text { Tobacco and betel }\end{array}$ & $\begin{array}{r}2.160 .000 \\
(17,99)\end{array}$ & $\begin{array}{r}2.400 .000 \\
(12,22)\end{array}$ & $-, 5,77$ \\
\hline & Jumlah/ Total & 15.444 .000 & 19.624 .000 & \\
\hline
\end{tabular}

Sumber : Data Primer diolah, 2009/ Source: Processing Primer Data, 2009.

Keterangan : Angka ( ) adalah prosentase/ Note: Numbers () is the percentage. 


\section{b. Pengeluaran Bukan Bahan Makanan}

Pengeluaran untuk bukan bahan makanan petambak garam dibagi dalam empat kelompok yang terdiri dari pengeluaran komunikasi/ telekomonikasi, pendidikan, kesehatan, dan sandang. Dari kelompok pengeluran ini, pengeluaran sandang merupakan pengeluaran terbesar di Desa Pinggir Papas berkisar antara Rp.1.200.000 sampai dengan Rp. 1.500.000,-. Rrata-rata pengeluaran sandang pada tahun 2008 adalah sebesar Rp.1.200.000/tahun, sedangkan pada tahun 2009 pengeluaran untuk sandang adalah Rp.1.500.000/tahun. Pengeluaran untuk biaya kesehatan merupakan pengeluaran ke dua setelah pengeluaran sandang yaitu di Desa Pinggir Papas, pengeluaran biaya untuk kesehatan pada tahun 2008 adalah Rp.250.000,- dan pada tahun 2009 sebesar Rp.300.000,-. Peningkatan ini mengindikasikan bahwa biaya kesehatan yang dikeluarkan bukan untuk penyakit yang berat dan serius melainkan biaya kesehatan untuk penyakit yang umum dan biasa terjadi.

Biaya pengeluaran untuk pendidikan relatif kecil bila dibandingkan dengan pengeluaran sandang dan kesehatan yaitu untuk di Desa Pinggir Papas. Pada tahun 2008 adalah Rp.150.000,- dan pada tahun 2009 sebesar Rp.300.000,. Berdasarkan pengeluaran biaya pendidikan ini yang masih relatif kecil menunjukan bahwa biaya pendidikan yang dikeluarkan setingkat sekolah dasar. Pengeluaran biaya pendidikan ini hanya terbatas pada pada biaya pembelian buku, tas sekolah, sepatu dan uang jajan, sedangkan untuk biaya sumbangan pendidikan (SPP) sudah gratis.

Biaya yang dikeluarkan untuk komunikasi atau telpon responden pada tahun 2008 adalah Rp.220.000, sedangkan pada tahun 2009 sebesar Rp.365.000. bertambahnya biaya komunikasi pada tahun 2009 desebabkan penggunaan telepon seluler responden untuk melakukan komunikasi untuk usaha kegiatan petambak garam. Sedangkan untuk pengeluaran lainnya terdiri dari dana sosial dan iuran keamanan untuk desa pada tahun 2008 adalah sebesar Rp. 350.000 dan pada tahun 2009 sebesar Rp. 400.000 .

Selisih pengeluaran Komunikasi pada tahun 2008 sampai 2009 untuk sebesar $65,9 \%$. Pengeluaran untuk biaya pendidikan mengalami kenaikan sampai $100 \%$. Pengeluaran ini hanya untuk pembelian buku dan alat alat tulis, sedangkan biaya pengeluaran perawatan kesehatan mengalami peningkatan sebesar $20 \%$.

Pengeluaran untuk kebutuhan sandang pada tahun 2009 mengalami kenaikan sebesar $25 \%$ dan pengeluaran lain-lainnya mengalami peningkatan sebesar $14,3 \%$. Sebaran tingkat pengeluaran bukan bahan makanan dapat dilihat pada Tabel 9.

\section{c. Pengeluaran Bahan Bakar}

Bahan bakar yang paling sering digunakan untuk keperluan sehari- hari adalah minyak tanah dan gas. Bensin merupakan bahan bakar pompa air untuk menaikkan air laut ke kolam penampungan, disamping untuk kebutuhan bahan bakar sepeda motor, sedangkan listrik untuk penerangan rumah.

Pengeluaran bahan bakar yang terjadi di antara kelompok pengeluaran bahan bakar minyak tanah merupakan pengeluaran terbesar pada 2008 sebesar 32,09\% dan pada tahun 2009 sebesar 19,91\% ,pengeluaran untuk minyak tanah mengalami penurunan sebesar $12,18 \%$, penurunan biaya pengeluaran minak tanah disebebkan bahan bakar minah tanah tidak bersubsidi dan sebagian masyarakat sudah beralih menggunakan elpiji dan kayu bakar. Pengeluaran untuk pembelian elpiji pada tahun 2008 sebesar 8,77\% dan pada tahun 2009 sebesar 17,07, pengeluaran elpiji mengalami peningkatan yaitu $106,9 \%$. Pengeluaran untuk minyak tanah mengalami penurunan yaitu sebesar $34,4 \%$. Penurunan ini disebabkan olah pengalihan bahan bakar yang digunakan yaitu dari gas elpiji dan kayu bakar. Pengeluaran untuk biaya listrik di desa Pingirpapas berkisar antara pada tahun 
Tabel 9. Pengeluaran Bukan Bahan Makanan Rumah Tangga Petambak Garam di Desa Pinggirpapas, Sumenep, 2008-2009.

Table 9. Non Fuel Expenditure of Salt Farmer's Houshold in Pinggirpapas Village of Sumenep, 2008-2009.

\begin{tabular}{|c|c|c|c|c|}
\hline \multirow[t]{2}{*}{ No } & \multirow[t]{2}{*}{$\begin{array}{l}\text { Jenis bahan bukan } \\
\text { makanan/ Type of } \\
\text { Material Non-Food }\end{array}$} & \multicolumn{3}{|c|}{$\begin{array}{l}\text { Pengeluaran bukan makanan di desa Pinggirpapas, } \\
\text { Sumenep/ Non-food expenditure in rural Pinggirpapas, } \\
\text { Sumenep }\end{array}$} \\
\hline & & 2008 & 2009 & $\begin{array}{c}\text { Selisish (\%)/ } \\
\text { Difference (\%) }\end{array}$ \\
\hline 1 & $\begin{array}{l}\text { Komunikasi/Telpon / } \\
\text { Communication / Phone }\end{array}$ & $\begin{array}{r}220.000 \\
(16,96)\end{array}$ & $\begin{array}{r}365.000 \\
(14,23)\end{array}$ & 65,9 \\
\hline 2 & Pendidikan/ Education & $\begin{array}{r}150.000 \\
(11,56 \%)\end{array}$ & $\begin{array}{r}300.000 \\
(10,47)\end{array}$ & 100 \\
\hline 3 & $\begin{array}{l}\text { Perawatan kesehatan/ } \\
\text { Health care }\end{array}$ & $\begin{array}{r}250.000 \\
(19,27)\end{array}$ & $\begin{array}{r}300.000 \\
(11,69)\end{array}$ & 20 \\
\hline 4 & Sandang/ Cloth & $\begin{array}{r}1.200 .000 \\
(92,52)\end{array}$ & $\begin{array}{r}1.500 .000 \\
(58,47)\end{array}$ & 25 \\
\hline 5 & Lainnya/ Other & $\begin{array}{r}350.000 \\
(26,98)\end{array}$ & $\begin{array}{r}400.000 \\
(15,59)\end{array}$ & 14,3 \\
\hline & Jumlah/Total & $\begin{array}{r}1.297 .000 \\
(100)\end{array}$ & $\begin{array}{r}2.865 .000 \\
(100)\end{array}$ & \\
\hline
\end{tabular}

Sumber : Data Primer diolah, 2009/ Source: Processing Primer Data, 2009

Keterangan : Angka ( ) adalah prosentase/ Note: Numbers () is the percentage

2008 mencapai Rp.600.000,- dan pada tahun 2009 sebesar Rp.624.000, sehingga terjadi kenaikan pengeluaran pada tahun 2009 sebesar $4 \%$.

Dalam transportasi dalam rangka kegiatan usaha penggaraman biaya yang dikeluarkan pembelian bensin pada tahun 2008 adalah Rp.150.000 dan pengeluaran pada tahun 2009 sebesar Rp. 175.000 selisih pengeluaran untuk kebutuhan bahan bakar bensin pada tahun 2009 adalah 16,7\%, sedangkan untuk pembelian minyak pelumas/ olie pada tahu 2008 sebesar Rp.180.000 dan pengeluaran pada tahun 2009 adalah Rp. 210.000 sedangkan selisih pengeluaran minyak pelumas pada tahun 2009 adalah $16,7 \%$.

Air merupakan salah satu kebutuhan rumah tangga yang sangat utama untuk kebutuhan rumah tangga, air yang digunakan sehari hariuntuk kebutuhan rumah tangga sebagian besar diperoleh melaui jaringan PDAM (Perusahaan Daerah Air Minum). Pengeluaran untuk air di Desa Pinggir Papas pada tahun 2008 adalah Rp.250.000 dan pada tahun 2009 sebesar Rp.320.000,-. Selisih biaya yang dikeluarkan pada tahun 2009 adalah sebesar $28 \%$.

\section{Permasalahan Usaha Tambak garam}

Usaha kegiatan pembuatan garam rakyat dihadapkan dengan beberapa permasalahan yang dipengaruhi oleh beberapa faktor, baik secara teknis maupun ekonomi.

\section{Aspek Teknis.}

Dalam teknis pembuatan garam khususnya yang dilakukan petambak garam rakyat terdapat permasalahan yakni kualitas 
Tabel 10. Pengeluaran Bahan Bakar Rumah Tangga Petambak Garam di desa Pinggirpapas, Sumenep, 2008-2009.

Table 10. Salt Farmer's Houshold Fuel Expenditures in Pinggirpapas VIllage of Sumenep, 2008-2009.

\begin{tabular}{|c|c|c|c|c|}
\hline \multirow[t]{2}{*}{ No } & \multirow{2}{*}{$\begin{array}{l}\text { Jenis bahan Bakar/ } \\
\text { Types of Fuel }\end{array}$} & \multicolumn{3}{|c|}{$\begin{array}{l}\text { Pengeluaran Bahan Bakar/ } \\
\text { Fuel Expenditure }\end{array}$} \\
\hline & & 2008 & 2009 & $\begin{array}{l}\text { Perubahan/ } \\
\text { Change }\end{array}$ \\
\hline 1 & Elpiji/ LPG & $\begin{array}{r}174.000 \\
(8,77)\end{array}$ & $\begin{array}{r}360.000 \\
(17,07)\end{array}$ & 106,9 \\
\hline 2 & $\begin{array}{l}\text { Minyak tanah/ } \\
\text { Kerosene }\end{array}$ & $\begin{array}{r}640.000 \\
(32,09)\end{array}$ & $\begin{array}{r}420.000 \\
(19,91)\end{array}$ & $-34,4$ \\
\hline 3 & Listrik/ Electricity & $\begin{array}{r}600.000 \\
(30,09)\end{array}$ & $\begin{array}{r}624.000 \\
(29,58)\end{array}$ & 4 \\
\hline 4 & $\begin{array}{l}\text { Minyak Pelumas / } \\
\text { Lubricant }\end{array}$ & $\begin{array}{r}180.000 \\
(9,03)\end{array}$ & $\begin{array}{r}210.000 \\
(9,95)\end{array}$ & 16,7 \\
\hline 5 & Bensin/ Gasoline & $\begin{array}{r}150.000 \\
(7,52)\end{array}$ & $\begin{array}{r}175.000 \\
(8,29)\end{array}$ & 16,7 \\
\hline 6 & Air/ Water & $\begin{array}{r}250.000 \\
(12,53)\end{array}$ & $\begin{array}{r}320.000 \\
(15,17)\end{array}$ & 28 \\
\hline & Jumlah/Total & $\begin{array}{r}1.994 .000 \\
(100)\end{array}$ & $\begin{array}{r}2.109 .000 \\
(100)\end{array}$ & 5,8 \\
\hline
\end{tabular}

Sumber : Data Primer diolah, 2009/ Source: Processing Primer Data, 2009.

Keterangan : Angka ( ) adalah prosentase/ Note: Numbers () is the percentage.

super premium yang menjadi standar mutu PT. Garam. Garam yang dihasilkan petani tambak garam maksimum hanya memiliki kualitas mutu P ( putih) dan M ( merah). Sedangkan untuk memenuhi kualitas mutu super premium yang ditetapkan PT. Garam, petani merasa kesulitan disebabkan untuk mendapatkan mutu tersebut diperlukan perlakuan khusus sejak lahan tambak garam dipersiapkan untuk pembuatan garam. Perlakuan khusus tersebut diantaranya adalah (a), lahan tambak garam jangan sekali-kali ditanami budidaya ikan karena apabila ditanami ikan maka lahan tambak garam tersebut yang siap untuk dijadikan tambak garam akan menjadi rusak, yang berakibat mempengaruhi mutu garam yang dihasilkan. Kemudian, (b), pada saat pemanenan garam yang diambil dari lahan tambak adalah garam yang sudah memiliki waktu penjemuran yang lama, sejak terbentuknya garam dilahan tambak, biasanya garam diambil setelah 10-20 hari dari waktu pemanenan yang biasanya dilakukan petambak. Garam yang diambil adalah bagian atasnya saja tidak langsung ke dasar tambak.

\section{Aspek Ekonomi}

Permasalahan yang timbul dalam pengelPermasalahan yang timbul dalam pengelolaan lahan tambak garam tidak hanya permasalahan aspek sosial dan teknis, akan tetapi mencakup aspek ekonomi seperti masih terdapatnya, perlunya solusi bagi petambak garan tidak merasa dirugikan. Permasalahan tersebut antara lain adalah harga yang berlaku oleh petambak yang dianggap tidak memihak ke petambak garam karena masih terlalu rendahnya kualitas garam. Saat ini harga garam sebesar 
Rp. 160.000,-/ ton. Meskipun harga yang berlaku dilepas ke pasaran, namun perusahaan garam yang menentukan. Bahkan ada perusahaan yang membuat ketentuan pembayaran harga garam dibayar sebagian dengan hasil produk lainnya dari perusahaan tersebut seperti rokok yang berkisar antara $5-10 \%$. Ketentuan ini sangat memberatkan petani, namun karena ini telah merupakan ketentuan dari perusahaan maka petani tidak berdaya menghadapi kondisi ini. Peranan lembaga- lembaga yang menaungi petambak garam tidak dapat menunjukkan perannya untuk menstabilkan harga garam. Hal ini bisa dimaklumi karena sebagian besar pengurus lembaga tersebut merangkap sebagai pengumpul garam dari perusahaan. Kemudian, petambak garam tidak dapat menjual langsung ke perusahaan dan harus melalui pedagang pengumpul dimana setiap ton pedagang pengumpul mendapatkan komisi sebesar Rp. 10.000,- / ton, Melalui pola ini, petambak tidak harus menanggung biaya karung dan pengangkutan ke perusahaan yang dituju, untuk karung yang berwarna biru Rp.1.700,- dan warna putih Rp.1.000,- dengan ukuran 50 kg.per buah

\section{KESIMPULAN DAN IMPLIKASI KEBIJAKAN}

Hasil riset menunjukkan bahwa hampir sebagian besar tingkat pendidikan responden petambak garam ádalah Iulusan SLTP 46,87\% dan umur responden merupakan umur yang produktif. Pengalaman usaha rata rata responden berkisar 10 sampai 20 tahun. dengan tanggungan keluarga petambak garam relatif cukup besar yaitu 3- 6 orang. Kepemilikan lahan tambak garam $70,60 \%$ milik sendiri dan sisanya sebagai penggarap. Sumber pendapatan petambak garam 53,13\% mengandalkan dari usaha garam, dan $28,12 \%$ bersumber dari Usaha pegaraman dan perikanan. Sedangkan petambak garam yang mata pencaharian lebih dari dua mata pencaharian adalah12,50\% yaitu garam dan Sembako.
Dinamika pendapatan petambak garam mengalami penurunan secara keseluruhan dari tahun 2008 sampai 2009 mengalami peningkatan sebesar 6,2\%. Pendapatan dari hasil budidaya pada tahun 2008 sebesar Rp. 1.850 .000 dan pada tahun 2009 sebesar Rp.2.300.000, atau sebesar $24,3 \%$, sedangkan pendapatan toko sembako pada tahun 2008 sebesar Rp. 13.750.000 dan pendapatan sembako tahun 2009 sebesar Rp.7.450.00, pendapatan dari sembako mengalami penurunan sebesar $45,8 \%$ Pengeluaran rumah tangga mengalami bahan makanan mengalami kenaikan sebesar 12,71\% dari tahun 2008 ke tahun 2009. Sedangkan pengeluaran untuk bukan bahan makanan mengalami kenaikan sebesar 22,09\% dan pengeluaran untuk bahan bakar pada tahun 2008 ke tahun 2009 mengalai kenaikan sebesar $5,8 \%$.

Dalam pembagian sistem hasil perlu dibuatkan peraturan yang lebih jelas atau dibuatkan peraturan desa tentang sistem bagi hasil, sehingga sistem abgi hasil dapat memihak kepada petambak garam.

Pengeluaran terbesar diserap oleh pengeluaran bahan makanan pokok, seiring dengan pendapatan peningkatan yang semakin tinggi, Pola pengeluaran petambak garam ditandai dengan pergeseran konsumsi beras cenderung menurun dan dapat digantikan oleh komoditas lain yang mengandung kabrohidrat lainnya. Pengeluaran yang paling besar adalah pengeluaran untuk bahan makan bila dibandingkan dengan pengeluaran lainnya, seperti bahan bukan makanan dan pengeluaran bahan bakar minyak.

Permasalahan dari aspek sosial, ekonomi dan teknis yang dihadapi petambak garam adalah perlunya penaganan segera mungkin. Aspek sosisl yang harus diperhatikan adalah meningkatkan sumberdaya petambak garam yang lebih maju dengan cara melakukan sosialisasi teknologi pembuatan garam. Bila ditinjau secara ekonomi harga garam sampai saat ini masih jauh dari harapan petani, sehingga perlu adanya ketentuan harga dasar garam. 
Pada saat bersamaan perlu adanya peket teknologi tepat guna untuk mendongkrak produksi garam yang lebih tinggi dengan kualitas yang lebih baik.

\section{DAFTAR PUSTAKA}

Jati, W dan Purwoko, 2009. Ironi industri garam nasional. Bisnis Indonesia, Senin 7 September.2009

Saad, S. 2004. Indonesia sebagai negara pengimpor garan sampai 2025.
Sugiarto. 2008. Analisis Pendapatan, Pola konsumsi dan Kesejahteraan Petani Padi Pada basis Agroekosistem Lahan Sawah Irigasi. Pusat Analisis Sosial Ekonomi Kebijakan Pertanian. Departemen Pertanian, Prosedisng Seminar Nasional Dinamika Pembangunan Pertanian dan Pedesaan : Tantangan dan Peluang bagi peningkatan kesejakteraan petani, Bogor 19 Nop. 2008. 1-13 hal.

Sumahamijaya, I, 2009. Indonesia, Negara 17.504 pulau yang impor garam. Majari Magazine No.1. Jakarta. 